Acta Crystallographica Section B

Structural Science, Crystal Engineering and Materials

ISSN 2052-5206

Bernardo Monteiro, ${ }^{\text {a José A. }}$ Fernandes, ${ }^{\text {b }}$ Cláudia C. L. Pereira, ${ }^{a}$ Sérgio M. F. Vilela, ${ }^{b}$ João P. C. Tomé, , d Joaquim Marçalo ${ }^{\mathrm{a}}$ and Filipe A. Almeida $\mathrm{Paz}^{\mathrm{b} *}$

${ }^{a}$ Centro de Ciências e Tecnologias Nucleares, Instituto Superior Técnico, Universidade de Lisboa, 2695-066 Bobadela LRS, Portugal, ${ }^{\text {b} C I C E C O}$, Departamento de Química, Universidade de Aveiro, Campus Universitário de Santiago, 3810-193 Aveiro, Portugal, ' QOPNA, Departamento de Química, Universidade de Aveiro, Campus Universitário de Santiago, 3810-193 Aveiro, Portugal, and dDepartment of Organic Chemistry, Ghent University, B-9000 Ghent, Belgium

Correspondence e-mail: filipe.paz@ua.pt

\title{
Metal-organic frameworks based on uranyl and phosphonate ligands
}

Three new crystalline metal-organic frameworks have been prepared from the reaction of uranyl nitrate with nitrilotris(methylphosphonic acid) $\left[\mathrm{H}_{6} \mathrm{nmp}, \mathrm{N}\left(\mathrm{CH}_{2} \mathrm{PO}_{3} \mathrm{H}_{2}\right)_{3}\right]$, 1,4phenylenebis(methylene)diphosphonic acid $\left[\mathrm{H}_{4} \mathrm{pmd}\right.$, $\left.\mathrm{C}_{6} \mathrm{H}_{4}\left(\mathrm{PO}_{3} \mathrm{H}_{2}\right)_{2}\right]$, and (benzene-1,3,5-triyltris(methylene))triphosphonic acid $\left[\mathrm{H}_{6} \mathrm{bmt}, \mathrm{C}_{6} \mathrm{H}_{3}\left(\mathrm{PO}_{3} \mathrm{H}_{2}\right)_{3}\right]$. Compound $\left[\left(\mathrm{UO}_{2}\right)_{2} \mathrm{~F}\left(\mathrm{H}_{3} \mathrm{nmp}\right)\left(\mathrm{H}_{2} \mathrm{O}\right)\right] \cdot 4 \mathrm{H}_{2} \mathrm{O}$ (I) crystallizes in space group $\mathrm{C} 2 / \mathrm{c}$, showing two crystallographically independent uranyl centres with pentagonal bipyramidal coordination geometries. While one metal centre is composed of a $\left\{\left(\mathrm{UO}_{2}\right) \mathrm{O}_{3}(\mu-\mathrm{F})\right\}_{2}$ dimer, the other comprises an isolated $\left\{\left(\mathrm{UO}_{2}\right) \mathrm{O}_{5}\right\}$ polyhedron. Compound $\left[\left(\mathrm{UO}_{2}\right)\left(\mathrm{H}_{2}\right.\right.$ pmd)] (II) crystallizes in space group $P 2_{1} / c$, showing a centrosymmetric uranyl centre with an octahedral $\left\{\left(\mathrm{UO}_{2}\right) \mathrm{O}_{4}\right\}$ coordination geometry. Compound $\left[\left(\mathrm{UO}_{2}\right)_{3}\left(\mathrm{H}_{3} \mathrm{bmt}\right)_{2}\left(\mathrm{H}_{2} \mathrm{O}\right)_{2}\right] \cdot 14 \mathrm{H}_{2} \mathrm{O}$ (III) crystallizes in space group $P \overline{1}$, showing two crystallographically independent uranyl centres. One uranyl centre is a $\left\{\left(\mathrm{UO}_{2}\right) \mathrm{O}_{5}\right\}$ pentagonal bipyramid similar to that in (I), while the other is a $\left\{\left(\mathrm{UO}_{2}\right) \mathrm{O}_{4}\right\}$ centrosymmetric octahedron similar to that in (II). Compounds (I) and (III) contain solvent-accessible volumes accounting for $c a 23.6$ and $26.9 \%$ of their unit-cell volume, respectively. In (I) the cavity has a columnar shape and is occupied by disordered water molecules, while in (III) the cavity is a two-dimensional layer with more ordered water molecules. All compounds have been studied in the solid state using FT-IR spectroscopy. Topological studies show that compounds (I) and (III) are trinodal, with 3,6,6- and 4,4,6connected networks, respectively. Compound (II) is instead a 4-connected uninodal network of the type cds.

\section{Introduction}

Metal-organic frameworks (MOFs) are nowadays typically prepared using hydrothermal synthetic approaches with the aim of obtaining crystalline products, in particular suitable large crystals for single-crystal diffraction. Most metal-organic assemblies involving $f$-block elements (Andrews \& Cahill, 2013) make use of polycarboxylate ligands, particularly those built around an aromatic skeleton which are, by themselves, a particularly notable subset (Thuéry et al., 2013). Our research group has been employing multipodal phosphonate-based organic linkers for the construction of MOFs with, mainly, rare-earth cations (Rocha et al., 2009; Cunha-Silva, Ananias et al., 2009; Cunha-Silva, Lima et al., 2009; Soares-Santos et al., 2010; Almeida Paz et al., 2004, 2005; Shi, Paz, Girginova, Amaral et al., 2006; Shi, Paz, Girginova, Rocha et al., 2006; Vilela, Mendes et al., 2013; Shi et al., 2008; Silva et al., 2011; Cunha-Silva et al., 2007; Silva et al., 2012; Vilela et al., 2012; Vilela, Firmino et al., 2013). The phosphonate group consti-
Received 19 September 2013 Accepted 28 December 2013 
tutes a suitable rigid building block for the construction of robust multi-dimensional networks because the existence of three $\mathrm{O}$ atoms placed at the vertices of a tetrahedron mimics well the basic building unit of zeolites and zeo-type materials. These units are, in this way, structurally and thermally more robust than carboxylates, ultimately leading to stronger connections with larger cations such as uranyl. Phosphonatebased MOFs are, nevertheless, considerably fewer in the literature than their carboxylate-based counterparts. This is due in part to the fact that phosphonates tend to form densely packed layered structures that are not porous. In addition, because of their lower solubility, metal phosphonates tend to be less crystalline than carboxylates. This often means that even if a phosphonate-based MOF is obtained, it must be structurally characterized by powder X-ray diffraction (PXRD) instead of single-crystal methods (Adelani et al., 2011). Notwithstanding, phosphonates have become a prominent family of ligands among those used in the synthesis of uranyl-organic frameworks (UOFs). Indeed, several groups have exploited the high affinity of phosphonic acids for uranyl to generate a large variety of original architectures, from onedimensional nanotubules up to three-dimensional frameworks (Thuéry, 2013).

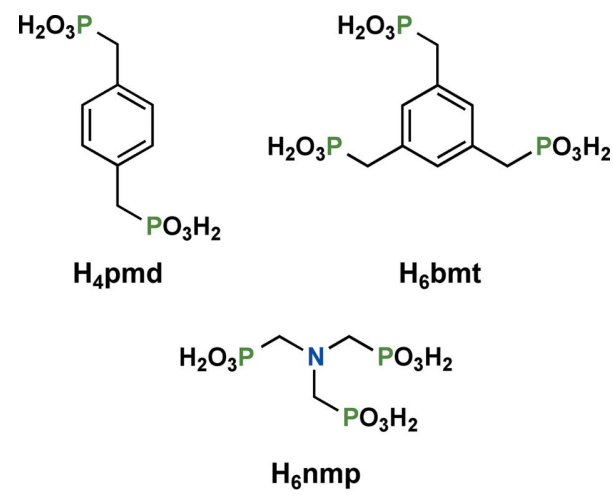

The richness in the structural chemistry of uranyl arises from the extremely flexible coordination chemistry of the uranyl cation, $\mathrm{UO}_{2}^{2+}$, commonly adopting the $\mathrm{UO}_{7}$ pentagonal bipyramidal geometry, but also yielding the less common $\mathrm{UO}_{6}$ tetragonal bipyramid and the $\mathrm{UO}_{8}$ hexagonal bipyramid (Alsobrook et al., 2011). In this current work, we have employed $\mathrm{UO}_{2}\left(\mathrm{NO}_{3}\right)_{2} \cdot 6 \mathrm{H}_{2} \mathrm{O}$ as the source of uranyl and three organic polyphosphonate linkers already used by us, namely 1,4-phenylenebis(methylene)diphosphonic acid $\left(\mathrm{H}_{4} \mathrm{pmd}\right)$ (Vilela, Mendes et al., 2013; Shi et al., 2008), nitrilotris(methylphosphonic acid) $\left(\mathrm{H}_{6} \mathrm{nmp}\right)$ (Silva et al., 2011, 2012; Cunha-Silva et al., 2007) and (benzene-1,3,5-triyltris(methylene))triphosphonic acid $\left(\mathrm{H}_{6} \mathrm{bmt}\right)$ (Vilela et al., 2012; Vilela, Firmino et al., 2013). Three new structures have been isolated and characterized, $\left[\left(\mathrm{UO}_{2}\right)_{2} \mathrm{~F}\left(\mathrm{H}_{3} \mathrm{~nm}\right.\right.$ $\left.\mathrm{p})\left(\mathrm{H}_{2} \mathrm{O}\right)\right] \cdot 4 \mathrm{H}_{2} \mathrm{O} \quad$ (I), $\quad\left[\left(\mathrm{UO}_{2}\right)\left(\mathrm{H}_{2} \mathrm{pmd}\right)\right] \quad$ (II) and $\left[\left(\mathrm{UO}_{2}\right)_{3}\left(\mathrm{H}_{3} \mathrm{bmt}\right)_{2}\left(\mathrm{H}_{2} \mathrm{O}\right)_{2}\right] \cdot 14 \mathrm{H}_{2} \mathrm{O}$ (III), with phase purity being confirmed using a combination of elemental analyses and FT-IR spectroscopy.

\section{Experimental}

\subsection{Materials and methods}

The organic ligand nitrilotris(methylenephosphonic acid) $\left[\mathrm{H}_{6} \mathrm{nmp}, \mathrm{N}\left(\mathrm{CH}_{2} \mathrm{PO}_{3} \mathrm{H}_{2}\right)_{3}, 97 \%\right.$, Fluka] is commercially available. 1,4-Phenylenebis(methylene)diphosphonic acid $\left(\mathrm{H}_{4} \mathrm{pmd}\right.$; Vilela, Mendes et al., 2013) and (benzene-1,3,5-triyltris(methylene) )triphosphonic acid $\left(\mathrm{H}_{6} \mathrm{bmt}\right.$; Vilela et al., 2012) were prepared according to published procedures.

Elemental analysis (CHN) was performed on a CE Instruments EA1110 automatic analyser. To guarantee complete combustion of the samples, a couple of milligrams of $\mathrm{V}_{2} \mathrm{O}_{5}$ were added during the analysis, and the results were corrected to reflect the addition of this substance. FT-IR spectra (range $4000350 \mathrm{~cm}^{-1}$ ) were collected as $\mathrm{KBr}$ pellets (Sigma-Aldrich, FT-IR grade) using a Bruker Tensor 27 spectrometer by averaging 200 scans at a maximum resolution of $4 \mathrm{~cm}^{-1}$.

\subsection{Hydrothermal synthesis}

Crystals of compounds (I) (III) were isolated by mixing $\mathrm{UO}_{2}\left(\mathrm{NO}_{3}\right)_{2} \cdot 6 \mathrm{H}_{2} \mathrm{O}$ and the appropriate organic ligand in deionized water (see below for the employed amounts). The reaction mixtures were then transferred into Teflon-lined $26 \mathrm{ml}$ autoclaves that were placed at $363 \mathrm{~K}$ for a period of $15 \mathrm{~h}$. A few drops of HF were added to the reaction mixtures to promote the isolation of phase-pure compounds (I) and (III). The addition of this mineralizing agent was not necessary for the preparation of crystalline compound (II).

2.2.1. $\left[\left(\mathrm{UO}_{2}\right)_{2} \mathbf{F}\left(\mathbf{H}_{3} \mathbf{n m p}\right)\left(\mathbf{H}_{2} \mathbf{O}\right)\right] \cdot \mathbf{4} \mathbf{H}_{2} \mathbf{O}$ (I). $150.0 \mathrm{mg}$ of $\mathrm{UO}_{2}\left(\mathrm{NO}_{3}\right)_{2} \cdot 6 \mathrm{H}_{2} \mathrm{O}(0.299 \mathrm{mmol})$ and $59.8 \mathrm{mg}$ of the ligand $\mathrm{H}_{6} \mathrm{nmp}(0.200 \mathrm{mmol})$ composed the initial reaction mixture. Elemental analysis: calc (\%): C 3.81, H 2.03, N 1.48; found: C 3.99, H 2.38, N 1.47.

2.2.2. [ $\left.\left(\mathbf{U O}_{\mathbf{2}}\right)\left(\mathbf{H}_{2} \mathbf{p m d}\right)\right]$ (II). $150.0 \mathrm{mg}$ of $\mathrm{UO}_{2}\left(\mathrm{NO}_{3}\right)_{2} \cdot 6 \mathrm{H}_{2} \mathrm{O}$ $(0.299 \mathrm{mmol})$ and $79.6 \mathrm{mg}$ of the ligand $\mathrm{H}_{4} \mathrm{pmd}(0.299 \mathrm{mmol})$ composed the initial reaction mixture. Elemental analysis: calc (\%): C 17.99, H 1.89; found: C 18.20, H 2.03 .

2.2.3. $\left[\left(\mathrm{UO}_{2}\right)_{3}\left(\mathbf{H}_{3} \mathbf{b m t}\right)_{2}\left(\mathbf{H}_{2} \mathrm{O}\right)_{2}\right] \cdot \mathbf{1 4} \mathbf{H}_{\mathbf{2}} \mathrm{O} \quad$ (III). $150.0 \mathrm{mg}$ $\mathrm{UO}_{2}\left(\mathrm{NO}_{3}\right)_{2} \cdot 6 \mathrm{H}_{2} \mathrm{O}(0.299 \mathrm{mmol})$ and $106.0 \mathrm{mg}$ of the ligand $\mathrm{H}_{6} \mathrm{bmt}(0.294 \mathrm{mmol})$ composed the initial reaction mixture. Elemental analysis: calc (\%): C 11.93, H 3.11; found: C 12.10, H 3.32 .

\subsection{Single-crystal $X$-ray diffraction}

Single crystals of (I) and (III) were harvested from the crystallization vials and immediately immersed in highly viscous FOMBLIN Y perfluoropolyether vacuum oil (LVAC 140/13, Sigma-Aldrich) to avoid degradation caused by evaporation of the solvent. Single crystals of (II) were harvested from the crystallization vials and immersed in silicon grease. All crystals were mounted on Hampton Research CryoLoops with the help of a Stemi 2000 stereomicroscope equipped with Carl Zeiss lenses (Kottke \& Stalke, 1993). Data were collected on a Bruker X8 Kappa APEX-II $\mathrm{CCD}$ area-detector diffractometer (graphite-monochromated Mo $K \alpha$ radiation, $\lambda=0.7107 \AA$ ) equipped with an Oxford 
Table 1

Experimental details.

Experiments were carried out with Mo K $\alpha$ radiation using a Bruker X8 Kappa CCD APEX-II diffractometer. Absorption was corrected for by multi-scan methods, $S A D A B S$ (Bruker, 2008). $\mathrm{H}$ atoms were treated by a mixture of independent and constrained refinement.

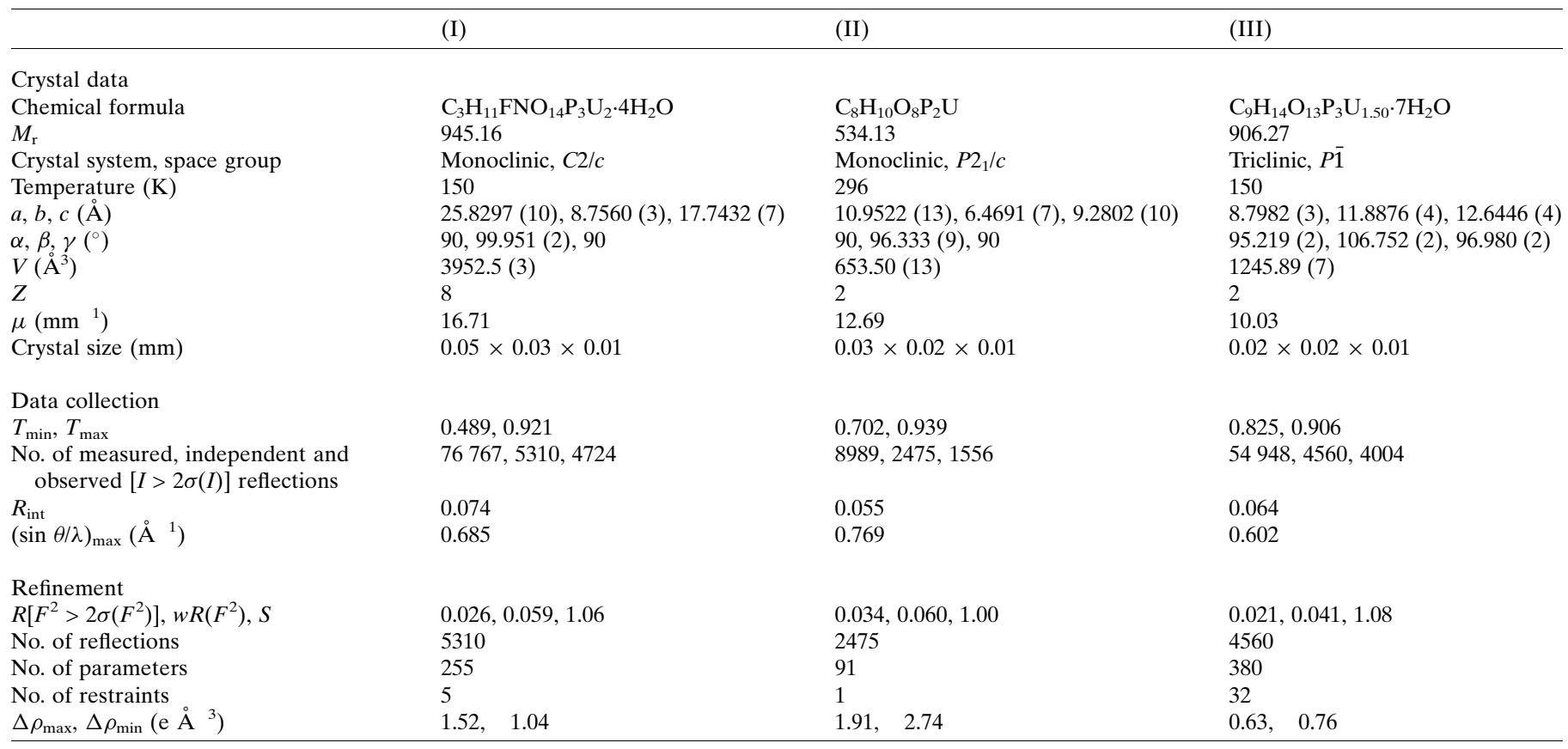

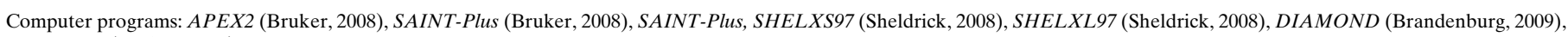
SHELXTL (Bruker, 2008).

Cryosystems Series 700 Cryostream monitored remotely using the software interface Cryopad (Oxford Cryosystems, 2006).

Some $\mathrm{O}$ atoms of the crystallization water molecules [all in compound (I) and two in compound (III)] were refined with a common isotropic displacement parameter. The remaining non- $\mathrm{H}$ atoms were successfully refined using anisotropic displacement parameters. $\mathrm{H}$ atoms bound to $\mathrm{C}$ were placed at idealized positions and allowed to ride during refinement with $U_{\text {iso }}(\mathrm{H})=1.2 U_{\text {eq }}(\mathrm{C}) . \mathrm{H}$ atoms bound to $\mathrm{O}$ or $\mathrm{N}$ [in (I)] belonging to the organic ligands were located from difference Fourier maps and refined with the $\mathrm{O} \quad \mathrm{H}$ and $\mathrm{N} \quad \mathrm{H}$ distances restrained to $0.95(1) \AA$. In some cases, additional antibumping restraints were added, namely $\mathrm{P} \cdots \mathrm{H}$ greater than 2.00 (1) $\AA$ in (I), and $\mathrm{H} \cdots \mathrm{H}$ greater than 2.16 (1) $\AA$ for atoms belonging to different water molecules in (III). The $\mathrm{H}$ atom bound to $\mathrm{O} 8$ in (I) was included as disordered over two different positions with assigned site occupancies of $0.5 . \mathrm{H}$ atoms belonging to the anisotropically refined water molecules in (III) were also located from difference Fourier maps and refined with the $\mathrm{O} \quad \mathrm{H}$ and $\mathrm{H} \cdots \mathrm{H}$ distances restrained to 0.95 (1) and 1.55 (1) $\AA$, respectively. The $\mathrm{H}$ atoms of the water molecules in (I) could not be located, and the atom sites in the structure are therefore $10 \mathrm{H}$ atoms per formula unit ( 80 per unit cell) short of the stated compound formula.

The final difference Fourier synthesis for the three compounds showed: for (I), the highest peak $\left(1.52 \mathrm{e} \AA^{-3}\right)$ located $0.94 \AA$ from U1 and the deepest hole $\left(-1.04 \mathrm{e} \AA^{-3}\right)$ $1.00 \AA$ from U2; for (II), the highest peak $\left(1.91 \mathrm{e}^{-3}\right)$ and the deepest hole $\left(-2.74 \mathrm{e}^{-3}\right)$ located 0.48 and $0.77 \AA$ from $\mathrm{U} 1$,

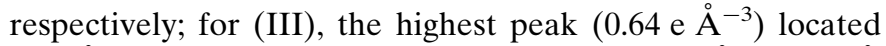
$0.17 \AA$ from $\mathrm{O} 2 W$ and the deepest hole $\left(-0.76 \mathrm{e} \AA^{-3}\right) 0.86 \AA$ from U2. Details of the crystallographic data collection and structure refinement are summarized in Table $1 .^{\mathbf{1}}$

\section{Results}

\subsection{Crystal structure of $\left[\left(\mathrm{UO}_{2}\right)_{2} \mathrm{~F}\left(\mathrm{H}_{3} \mathrm{nmp}\right)\left(\mathrm{H}_{2} \mathrm{O}\right)\right] \cdot 4 \mathrm{H}_{2} \mathrm{O}$ (I)}

Compound (I) crystallizes in space group $C 2 / c$, with the asymmetric unit being composed of a whole residue of nitrilotris(methylenephosphonic acid) $\left(\mathrm{H}_{3} \mathrm{nmp}^{3-}\right)$, two crystallographically independent uranyl centres, a coordinated water molecule, a coordinated fluoride anion and four water molecules distributed among ten distinct crystallographic locations with fractional site occupancies (Fig. 1a). The presence of fluoride in the structure was proven by the combination of data arising from different characterization methods: on the one hand, the usage of a few drops of HF in the synthesis is crucial (see $\$ 2$ ), since elimination of this step fails to lead to the same compound; on the other hand, both the elemental analysis and the performed crystallographic studies unequivocally show that these anions are present.

The coordination geometries around the metal centres resemble slightly distorted pentagonal bipyramids, with the oxo groups occupying the apical positions (see Table 2 for details). The equatorial positions of the coordination poly-

\footnotetext{
${ }^{\mathbf{1}}$ Supporting information for this paper is available from the IUCr electronic archives (Reference: BI5030).
} 
Table 2

Selected bond lengths and angles $\left(\AA,^{\circ}\right)$ for the $\mathrm{U}^{6+}$ coordination environments in (I).

\begin{tabular}{|c|c|c|c|c|c|c|}
\hline U1 & O10 & & $1.764(4)$ & U2 & $\mathrm{O} 13$ & 1.767 (4) \\
\hline U1 & O11 & & 1.769 (4) & U2 & $\mathrm{O} 12$ & $1.770(4)$ \\
\hline U1 & $\mathrm{O} 4$ & & $2.323(4)$ & U2 & O5 & 2.307 (3) \\
\hline U1 & O1 & & $2.331(4)$ & U2 & $\mathrm{O} 6^{\mathrm{iii}}$ & $2.311(3)$ \\
\hline U1 & $O 9^{\mathrm{i}}$ & & $2.354(4)$ & $\mathrm{U} 2$ & F1 & $2.351(3)$ \\
\hline U1 & $\mathrm{O} 2^{\mathrm{ii}}$ & & $2.368(4)$ & $\mathrm{U} 2$ & $\mathrm{~F} 1^{\mathrm{iv}}$ & $2.336(3)$ \\
\hline \multirow[t]{2}{*}{ U1 } & \multirow{2}{*}{\multicolumn{2}{|c|}{$\mathrm{O} 1 W$}} & $2.510(4)$ & & $\mathrm{O}^{\mathrm{i}}$ & $2.355(4)$ \\
\hline & & & & \multicolumn{2}{|c|}{$\mathrm{U} 2 \cdots \mathrm{U} 2^{\mathrm{iv}}$} & $3.9829(3)$ \\
\hline $\mathrm{O} 10$ & U1 & O11 & 177.74 (19) & $\mathrm{O} 13$ & U2 $\mathrm{O} 12$ & $179.02(17)$ \\
\hline O10 & U1 & $\mathrm{O} 4$ & 84.27 (17) & $\mathrm{O} 13$ & U2 O5 & $88.77(15)$ \\
\hline O11 & U1 & $\mathrm{O} 4$ & 97.91 (17) & $\mathrm{O} 12$ & U2 O5 & 91.88 (15) \\
\hline $\mathrm{O} 10$ & $\mathrm{U} 1$ & $\mathrm{O} 1$ & 95.15 (17) & $\mathrm{O} 13$ & $\mathrm{U} 2 \mathrm{O}^{\mathrm{iii}}$ & 89.78 (15) \\
\hline O11 & U1 & $\mathrm{O} 1$ & 86.01 (16) & $\mathrm{O} 12$ & U2 $\mathrm{O}^{\mathrm{iii}}$ & 91.04 (16) \\
\hline $\mathrm{O} 4$ & U1 & $\mathrm{O} 1$ & 75.54 (13) & $\mathrm{O} 5$ & U2 O6 $^{\mathrm{iii}}$ & $79.54(12)$ \\
\hline $\mathrm{O} 10$ & U1 & $O 9^{i}$ & 93.82 (17) & $\mathrm{O} 13$ & $\mathrm{U} 2 \quad \mathrm{~F} 1^{\text {iv }}$ & 90.48 (14) \\
\hline O11 & $\mathrm{U} 1$ & $09^{\mathrm{i}}$ & 86.23 (17) & O12 & $\mathrm{U} 2 \quad \mathrm{~F} 1^{\mathrm{iv}}$ & 88.57 (15) \\
\hline $\mathrm{O} 4$ & U1 & $O 9^{i}$ & $73.50(13)$ & O5 & $\mathrm{U} 2 \quad \mathrm{~F} 1^{\mathrm{iv}}$ & $146.73(11)$ \\
\hline O1 & U1 & $O 9^{i}$ & $146.64(13)$ & $\mathrm{O} 6^{\mathrm{iii}}$ & $\mathrm{U} 2 \quad \mathrm{~F} 1^{\mathrm{iv}}$ & $133.72(11)$ \\
\hline $\mathrm{O} 10$ & U1 & $\mathrm{O} 2^{\mathrm{ii}}$ & 85.63 (17) & $\mathrm{O} 13$ & $\mathrm{U} 2 \quad \mathrm{~F} 1$ & 88.66 (14) \\
\hline O11 & U1 & $\mathrm{O} 2^{\mathrm{ii}}$ & 92.70 (17) & $\mathrm{O} 12$ & U2 F1 & 91.14 (15) \\
\hline $\mathrm{O} 4$ & U1 & $\mathrm{O} 2^{\mathrm{ii}}$ & 151.51 (14) & $\mathrm{O} 5$ & $\mathrm{U} 2 \quad \mathrm{~F} 1$ & 149.54 (11) \\
\hline O1 & U1 & $\mathrm{O} 2^{\mathrm{ii}}$ & 78.94 (13) & $\mathrm{O} 6^{\mathrm{iii}}$ & U2 F1 & 70.11 (11) \\
\hline $\mathrm{O} 9^{\mathrm{i}}$ & U1 & $\mathrm{O} 2^{\mathrm{ii}}$ & $133.83(13)$ & $\mathrm{F} 1^{\text {iv }}$ & $\mathrm{U} 2 \quad \mathrm{~F} 1$ & $63.63(11)$ \\
\hline O10 & U1 & $\mathrm{O} 1 W$ & 88.73 (18) & $\mathrm{O} 13$ & $\mathrm{U} 2 \quad \mathrm{O}^{\mathrm{i}}$ & 90.02 (15) \\
\hline O11 & U1 & $\mathrm{O} 1 W$ & 89.24 (17) & $\mathrm{O} 12$ & $\mathrm{U} 2 \quad \mathrm{O} 7^{\mathrm{i}}$ & 89.43 (16) \\
\hline $\mathrm{O} 4$ & U1 & $\mathrm{O} 1 W$ & $137.52(13)$ & O5 & $\mathrm{U} 2 \quad \mathrm{O}^{\mathrm{i}}$ & 76.57 (12) \\
\hline O1 & U1 & $\mathrm{O} 1 W$ & $146.92(13)$ & $\mathrm{O} 6^{\mathrm{iii}}$ & $\mathrm{U} 2 \quad \mathrm{O}^{\mathrm{i}}$ & $156.11(12)$ \\
\hline $\mathrm{O} 9^{\mathrm{i}}$ & $\mathrm{U} 1$ & $\mathrm{O} 1 W$ & $65.24(13)$ & $\mathrm{F} 1^{\mathrm{iv}}$ & $\mathrm{U} 2 \quad \mathrm{O}^{\mathrm{i}}$ & 70.17 (11) \\
\hline $\mathrm{O} 2^{\mathrm{ii}}$ & U1 & $\mathrm{O} 1 W$ & 68.60 (13) & $\mathrm{F} 1$ & $\mathrm{U} 2 \quad \mathrm{O}^{\mathrm{i}}$ & 133.77 (11) \\
\hline
\end{tabular}

Symmetry codes: (i) $x, \quad y+1, z+\frac{1}{2}$; (ii) $\quad x+1, y, \quad z+\frac{1}{2}$; (iii) $\quad x+\frac{1}{2}, y \quad \frac{1}{2}, \quad z+\frac{1}{2}$; (iv) $x+\frac{1}{2}, \quad y+\frac{1}{2}, \quad z+1$
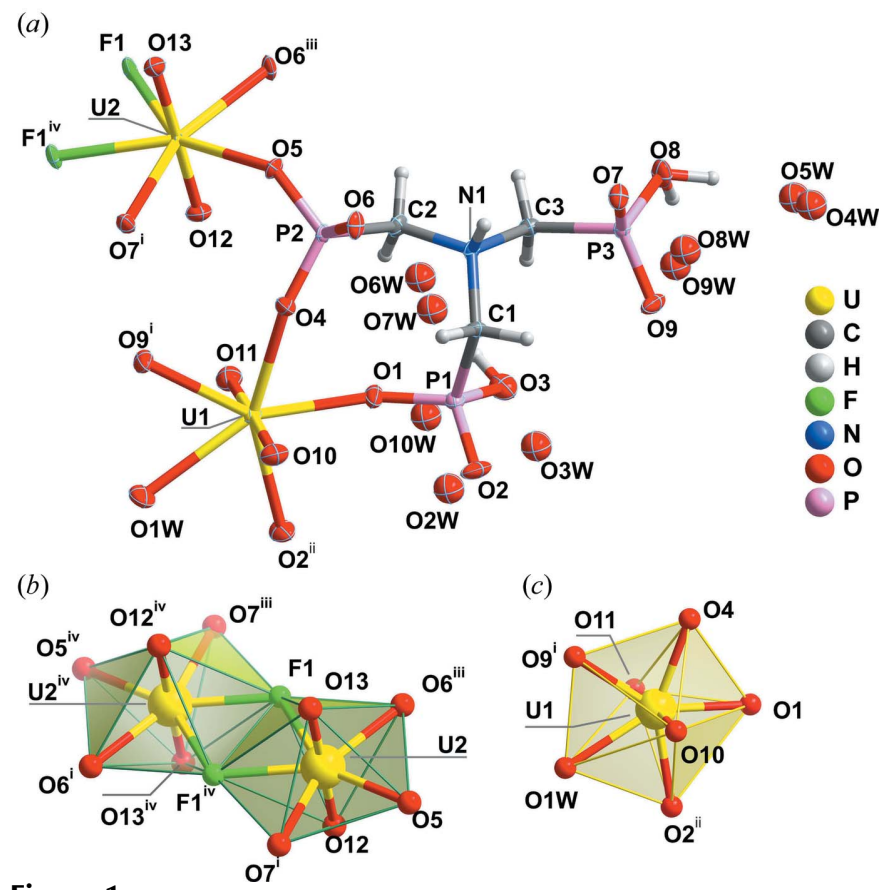

Figure 1

(a) Molecular units in (I). Non $\mathrm{H}$ atoms are represented as displacement ellipsoids drawn at $50 \%$ probability, while $\mathrm{H}$ atoms are represented as small spheres with arbitrary radii. Atom $\mathrm{O} 8$ is bonded to two $\mathrm{H}$ atoms, each with site occupancy $0.50 ;(b)$ and $(c)$ coordination geometries around $\mathrm{U} 2$ and U1, respectively. Symmetry codes are defined in Table 2.
Table 3

Hydrogen bond geometry $\left(\AA,^{\circ}\right)$ for $(\mathrm{I})$.

\begin{tabular}{llllll}
\hline$D$ & $\mathrm{H} \cdots A$ & $D \mathrm{H}$ & $\mathrm{H} \cdots A$ & $D \cdots A$ & $D \quad \mathrm{H} \cdots A$ \\
\hline $\mathrm{N} 1$ & $\mathrm{H} 1 Z \cdots \mathrm{F}^{\mathrm{v}}$ & $0.95(1)$ & $1.81(3)$ & $2.705(5)$ & $157(5)$ \\
$\mathrm{O} 3$ & $\mathrm{H} 3 Z \cdots \mathrm{O} 6 W$ & $0.96(1)$ & $2.19(2)$ & $3.139(13)$ & $175(6)$ \\
$\mathrm{O} 3$ & $\mathrm{H} 3 Z \cdots \mathrm{O} 7 W$ & $0.96(1)$ & $1.70(2)$ & $2.643(13)$ & $171(5)$ \\
$\mathrm{O} 8$ & $\mathrm{H} 8 Y \cdots \mathrm{O} 4 W$ & $0.95(1)$ & $1.88(4)$ & $2.802(10)$ & $163(13)$ \\
$\mathrm{O} 8$ & $\mathrm{H} 8 Y \cdots \mathrm{O} 5 W$ & $0.95(1)$ & $1.62(3)$ & $2.560(13)$ & $171(14)$ \\
$\mathrm{O} 8$ & $\mathrm{H} 8 X \cdots \mathrm{O} 8 W$ & $0.95(1)$ & $1.90(2)$ & $2.850(11)$ & $176(13)$ \\
$\mathrm{O} 8$ & $\mathrm{H} 8 X \cdots \mathrm{O} 9 W$ & $0.95(1)$ & $2.48(3)$ & $3.415(17)$ & $170(12)$ \\
\hline
\end{tabular}

Symmetry code: (v) $x+\frac{1}{2}, y+\frac{1}{2}, \quad z+\frac{1}{2}$.

Table 4

Selected bond lengths and angles $\left(\AA,^{\circ}\right)$ for the $\mathrm{U}^{6+}$ coordination environments in (II).

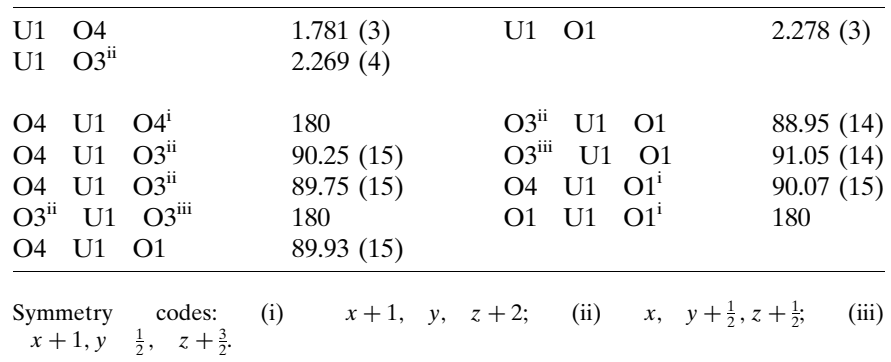

hedron around $\mathrm{U} 1$ are occupied by a coordinated water molecule and four $\mathrm{O}$ atoms from the organic ligands. The bond lengths are 1.764 (4) and 1.769 (4) $\AA$ for U1 = O, 2.510 (4) $\AA$ for U1 $\mathrm{O}_{\text {water }}$ and in the range 2.323 (4) 2.368 (4) $\AA$ for $\mathrm{U} 1 \mathrm{O}_{\text {phosphonate. The mean plane formed by the equatorial }}$ atoms and the metal centre [largest deviation of 0.245 (4) $\AA$ for O4] subtends angles with the axial $\mathrm{U}=\mathrm{O}$ bonds of $88.45(16)$ and $89.26(16)^{\circ}$. The equatorial cis O U1 O angles range from $65.24(13)$ to $78.94(13)^{\circ}$ (Fig. 1c). The coordination environment around U2 resembles a centrosymmetric bimetallic cluster bridged by two crystallographically equivalent fluoride anions. The remaining three equatorial positions are occupied by $\mathrm{O}$ atoms belonging to the organic ligands. The bonding distances are $1.767(4)$ and 1.770 (4) $\AA$ for $\mathrm{U} 2=\mathrm{O}$, between 2.307 (3) and 2.355 (3) $\AA$ for U2 $\mathrm{O}_{\text {phosphonate, }}$ and 2.336 (3) and 2.351 (3) A for U2 F. The $\mathrm{U}$...U distance in the dimer is 3.9829 (3) $\AA$. The mean plane formed by the equatorial atoms and the metal centre [largest deviation of 0.037 (3) $\AA$ for F1] subtends angles with the axial $\mathrm{U}=\mathrm{O}$ bonds of $88.48(15)$ and $89.44(15)^{\circ}$. The equatorial $\mathrm{cis}$ $\mathrm{O}$ U1 O angles range from 63.63 (11) to $79.44(12)^{\circ}$ (Fig. $1 b$ ). The organic residue $\mathrm{H}_{3} \mathrm{nmp}^{3-}$ is coordinated to six metal centres, with one of the phosphonate groups coordinated to the metal as a $\mu_{3}-\mathrm{O}, \mathrm{O}^{\prime}, \mathrm{O}^{\prime \prime}$-ligand, and the two $\mathrm{PO}_{3} \mathrm{H}$ groups as $\mu_{2}-\mathrm{O}, \mathrm{O}^{\prime}$-ligands. The remaining charge-balancing proton is bonded to the central N1 atom.

As the structure does not show any noticeable void volume, we conclude that all of the water molecule sites in the crystal structure have been found. These molecules are, however, included with fractional site occupancies, and their $\mathrm{H}$ atoms could not be located from difference Fourier maps. This means that the water molecules are loosely located and suffer from 


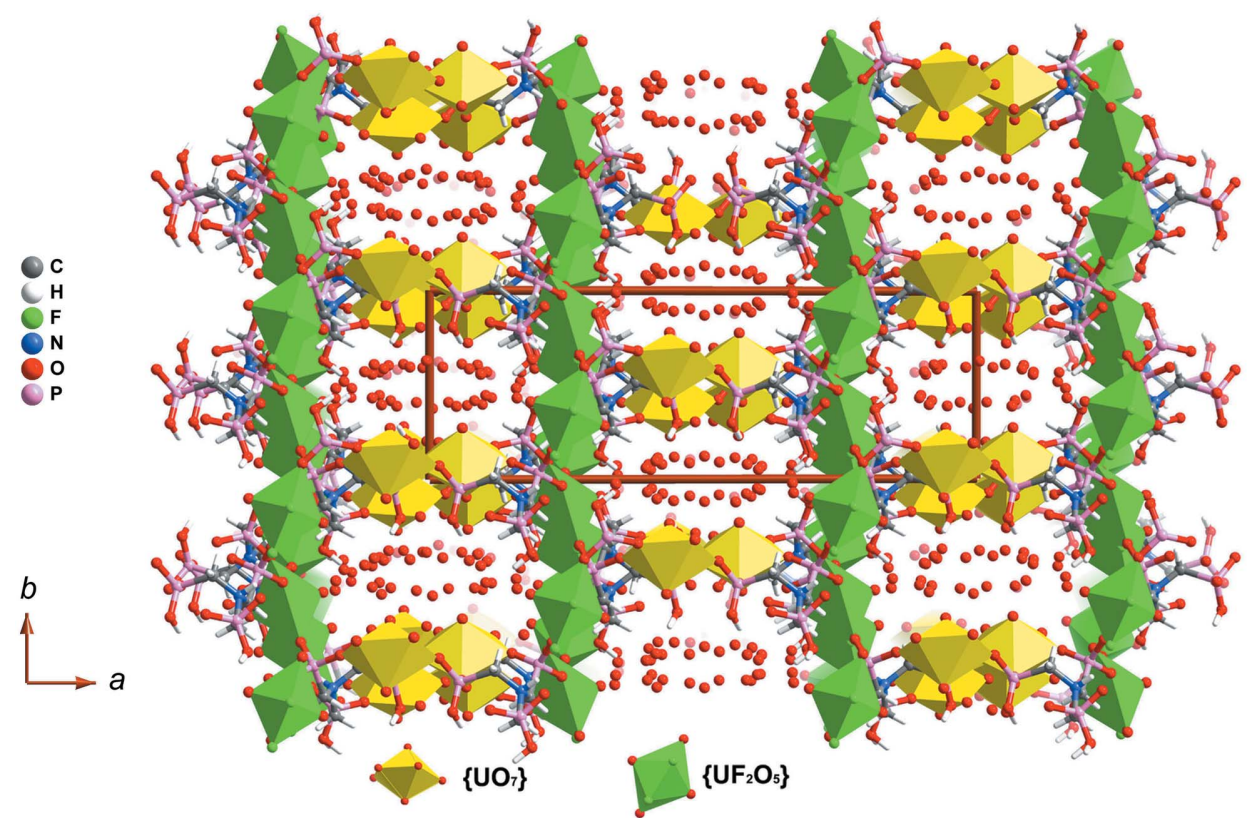

Figure 2

Crystal packing of (I) viewed along the [001] direction. The metal centres are represented as green or yellow polyhedra, depending on whether their coordination environment contains $\mathrm{F}$ atoms. $\mathrm{H}$ atoms of the water molecules were not located and, for this reason, the water molecules appear as isolated $\mathrm{O}$ atoms.

While the $\mathrm{O} 3$ atom donates its $\mathrm{H}$ atom to a pair of close, and fractionally occupied, water molecules, atom $\mathrm{O} 8$ appears to be connected to two half-occupied $\mathrm{H}$ atoms, with these being donated to two pairs of close and fractionally occupied water molecules (see Table 3 and Fig. 1 for details). The water molecules occupy a continuous column parallel to the $c$ direction of the unit cell (Fig. 2). This column has a cross section of $c a 10 \times 5 \AA^{2}$, accounting for $c a 23.6 \%$ of the total volume of the unit cell ( ca $932 \AA^{3}$ ).

\subsection{Crystal structure of [( $\left.\left.\mathrm{UO}_{2}\right)\left(\mathrm{H}_{2} \mathrm{pmd}\right)\right]$ (II)}

Compound (II) crystallizes in space group $P 2_{1} / c$, with the asymmetric unit being composed of half a 1,4-phenylenebis(methylene)diphosphonic acid ligand $\left(\mathrm{H}_{2} \mathrm{pmd}^{2-}\right)$, a $\mathrm{U}^{6+}$ metal centre occupying an inversion centre, and one oxo ligand (Fig. 3a). The coordination

spatial and conformational disorder, and for this reason the hydrogen-bond network cannot be described completely. The interaction $\mathrm{N} 1 \mathrm{H} 1 \mathrm{Z} \cdot \mathrm{F} 1$ is the only hydrogen bond with an unequivocal connection between a donor and an acceptor.

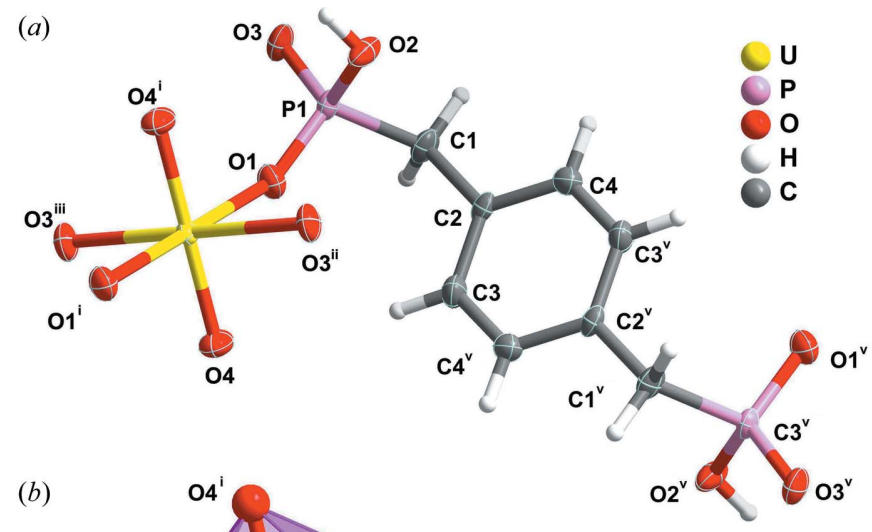

(b)

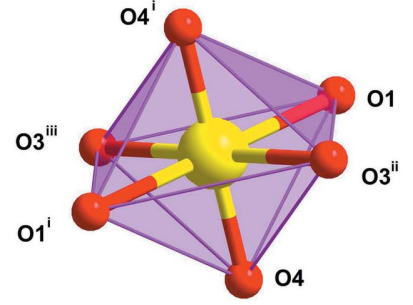

Figure 3

(a) Molecular units in (II). Non $\mathrm{H}$ atoms are represented as displacement ellipsoids at $50 \%$ probability, while $\mathrm{H}$ atoms are represented as small spheres with arbitrary radii; $(b)$ coordination geometry around the metal centre. Symmetry codes are defined in Table 4, and: (v) $x+2, \quad y, \quad z+2$. geometry around the centrosymmetric metal centre resembles an octahedron squeezed along the axis defined by the crystallographically equivalent oxo ligands (Fig. 3b). The remaining positions of the coordination environment are occupied by four $\mathrm{O}$ atoms from the organic ligands. The bond lengths are 1.781 (3) $\AA$ for $\mathrm{U} 1=\mathrm{O}$, and 2.269 (4) and 2.278 (3) $\AA$ for $\mathrm{U} 1 \mathrm{O}_{\text {phosphonate. While the equatorial cis }}$ octahedral $\mathrm{O} \mathrm{U} 1 \mathrm{O}$ angles range from $88.95(14)$ to

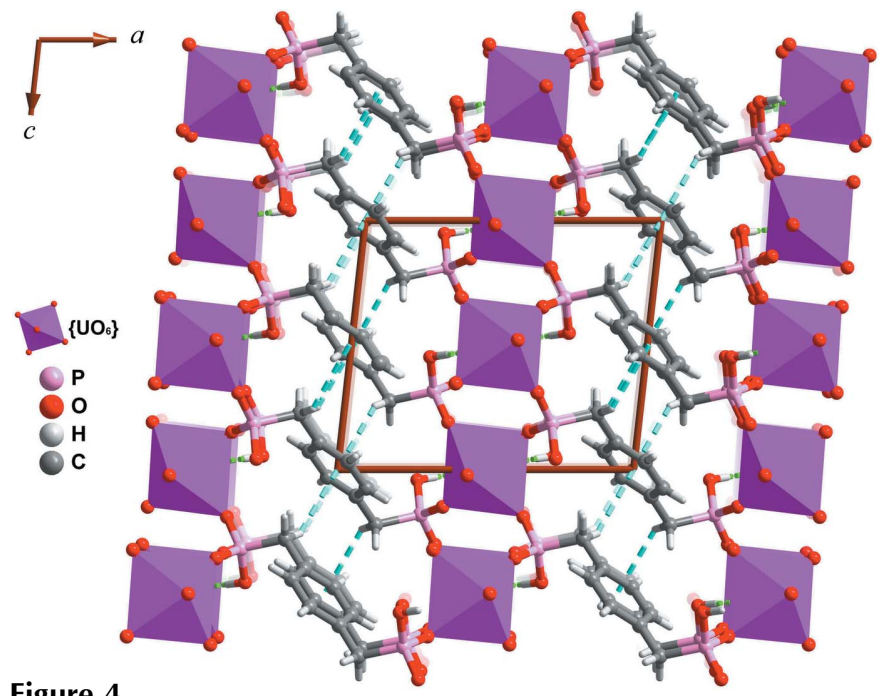

Figure 4

Crystal packing of (II) viewed along the [010] direction. Metal centres are represented as rose coloured squeezed octahedra. $\mathrm{O} \quad \mathrm{H} \quad \mathrm{O}$ and $\mathrm{C}$ $\mathrm{H} \pi$ interactions are depicted as green and blue dashed lines, respectively. 
Table 5

Hydrogen bond geometry $\left(\AA,^{\circ}\right)$ for (II).

\begin{tabular}{|c|c|c|c|c|c|}
\hline$D$ & $\mathrm{H} \cdots A$ & $D \quad \mathrm{H}$ & $\mathrm{H} \cdots A$ & $D \cdots A$ & $D \quad \mathrm{H} \cdots A$ \\
\hline $\mathrm{O} 2$ & $\mathrm{H} 2 Z \cdots \mathrm{O} 4^{\mathrm{iv}}$ & $0.83(1)$ & $1.88(2)$ & $2.703(5)$ & $168(5)$ \\
\hline $\mathrm{C} 1$ & $\mathrm{H} 1 B \cdots C g$ & 0.97 & 2.86 & $3.588(5)$ & 133 \\
\hline
\end{tabular}

$\mathrm{Cg}$ is the centroid of the ring composed by the atoms $\mathrm{C} 2^{\mathrm{vi}}, \mathrm{C} 3^{\mathrm{vi}}, \mathrm{C}^{\mathrm{vi}}, \mathrm{C}^{\mathrm{vii}}, \mathrm{C}^{\mathrm{vii}}$ and $\mathrm{C} 4^{\mathrm{vii}}$. Symmetry codes: (iv) $x, y+1, z$; (vi) $x, y+\frac{1}{2}, z \quad \frac{1}{2}$; (vii) $x+2, y+\frac{1}{2}, \quad z+\frac{3}{2}$.

Table 6

Selected bond lengths and angles $\left(\AA,^{\circ}\right)$ for the $\mathrm{U}^{6+}$ coordination environments in (III).

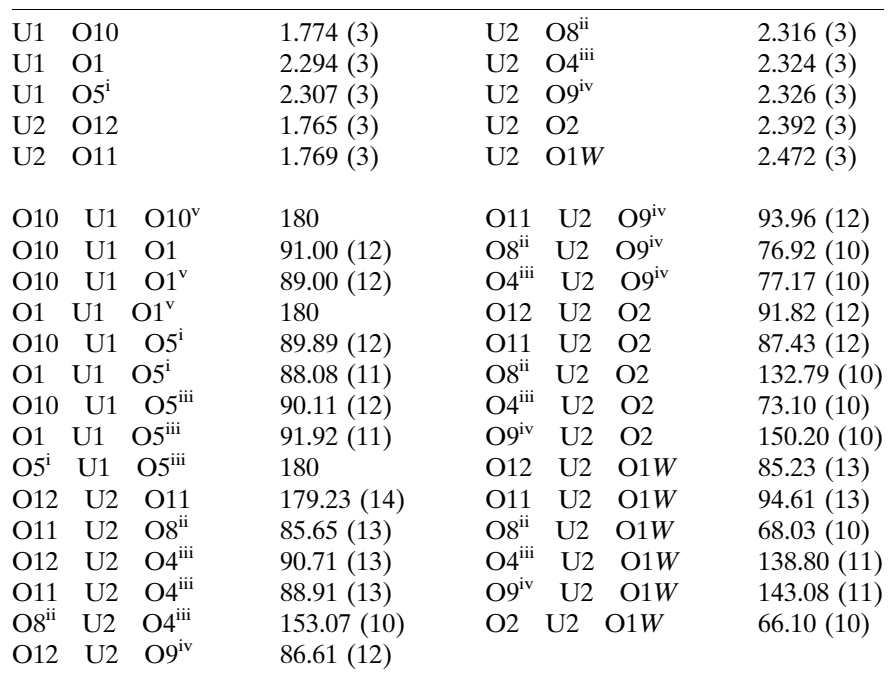

Symmetry codes: (i) $x+1, y, z$; (ii) $x, y, z+1$; (iii) $x, y+1, \quad z+1$; (iv) $x, y, z \quad 1 ;(\mathrm{v}) \quad x+1, \quad y+1, \quad z+1$.

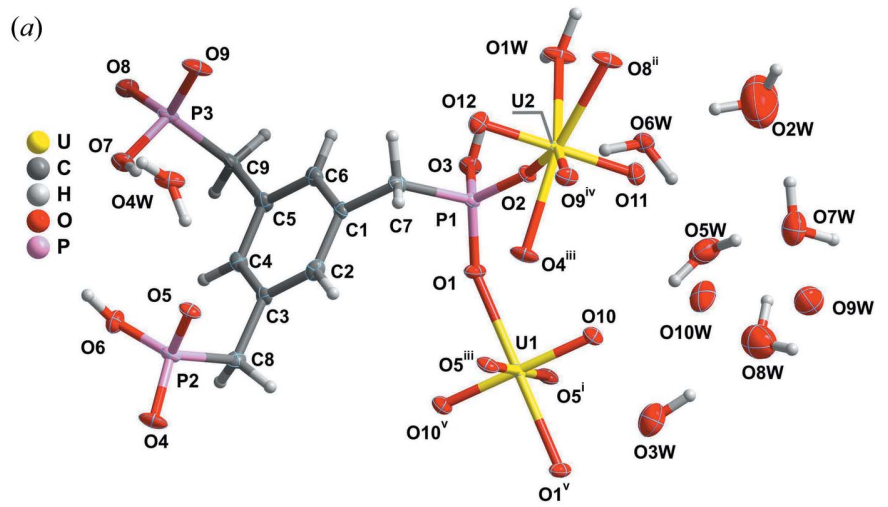

(b)
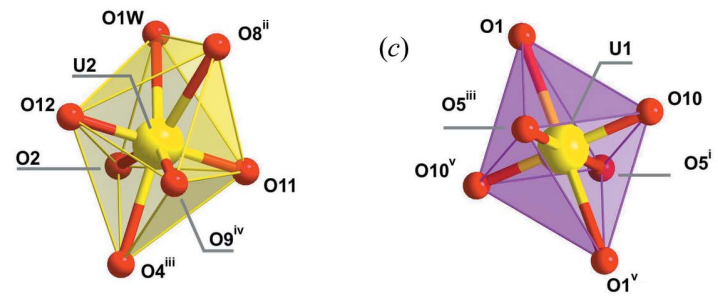

Figure 5

(a) Molecular units in (III). Non $\mathrm{H}$ atoms are represented as displace ment ellipsoids at $50 \%$ probability, while $\mathrm{H}$ atoms are represented as small spheres with arbitrary radii; $(b)$ and $(c)$ coordination geometries around U2 and U1, respectively. Symmetry codes as in Table 6.
Table 7

Hydrogen bond geometry $\left(\AA{ }^{\circ}\right)$ for (III).

\begin{tabular}{|c|c|c|c|c|}
\hline$D \quad \mathrm{H} \cdots A$ & $D \mathrm{H}$ & $\mathrm{H} \cdots A$ & $D \cdots A$ & $D \quad \mathrm{H} \cdots A$ \\
\hline $\mathrm{O} 3 \quad \mathrm{H} 3 Z \cdots \mathrm{O} 6 W^{\mathrm{vi}}$ & $0.94(1)$ & $1.69(1)$ & $2.625(4)$ & $168(4)$ \\
\hline O6 $\mathrm{H} 6 Z \cdots \mathrm{O} 3 W^{\mathrm{iii}}$ & $0.94(1)$ & $1.68(1)$ & $2.609(5)$ & $168(4)$ \\
\hline $\mathrm{O} 7 \mathrm{H} 7 \mathrm{Z} \cdots \mathrm{O} 4 \mathrm{~W}$ & $0.94(1)$ & $1.76(1)$ & $2.696(4)$ & $171(5)$ \\
\hline $\mathrm{O} 1 W \quad \mathrm{H} 1 X \cdots \mathrm{O} 6 W^{\mathrm{vi}}$ & $0.95(1)$ & $1.80(1)$ & $2.747(4)$ & $173(4)$ \\
\hline $\mathrm{O} 1 W \quad \mathrm{H} 1 Y \cdots \mathrm{O} 4 W^{\mathrm{ii}}$ & $0.95(1)$ & $1.86(2)$ & $2.752(5)$ & $156(5)$ \\
\hline $\mathrm{O} 2 W \quad \mathrm{H} 2 X \cdots \mathrm{O} 7 W^{\mathrm{vii}}$ & $0.95(1)$ & $2.18(6)$ & $3.002(9)$ & $144(8)$ \\
\hline $\mathrm{O} 2 W \quad \mathrm{H} 2 Y \cdots \mathrm{O} 11$ & $0.95(1)$ & $2.15(5)$ & $3.010(8)$ & $150(9)$ \\
\hline $\mathrm{O} 3 W \quad \mathrm{H} 3 X \cdots \mathrm{O} 8 W$ & $0.95(1)$ & $1.85(1)$ & $2.799(7)$ & $175(4)$ \\
\hline $\mathrm{O} 3 W \quad \mathrm{H} 3 Y \cdots \mathrm{O} 10$ & $0.95(1)$ & $2.67(4)$ & $3.336(5)$ & $128(4)$ \\
\hline $\mathrm{O} 3 W \quad \mathrm{H} 3 Y \cdots \mathrm{O} 1^{\mathrm{v}}$ & $0.95(1)$ & $2.59(3)$ & $3.333(5)$ & $136(3)$ \\
\hline $\mathrm{O} 4 W \quad \mathrm{H} 4 X \cdots \mathrm{O} 3^{\text {viii }}$ & $0.95(1)$ & $1.95(2)$ & $2.841(5)$ & $156(4)$ \\
\hline $\mathrm{O} 4 W \quad \mathrm{H} 4 Y \cdots \mathrm{O} 5$ & $0.95(1)$ & $2.12(2)$ & $3.031(4)$ & $161(4)$ \\
\hline $\mathrm{O} 5 W \quad \mathrm{H} 5 X \cdots \mathrm{O} 10$ & $0.95(1)$ & $2.07(2)$ & $2.989(5)$ & $163(4)$ \\
\hline $\mathrm{O} 5 W \quad \mathrm{H} 5 Y \cdots \mathrm{O} 7 W$ & $0.95(1)$ & $1.87(1)$ & $2.823(7)$ & $174(3)$ \\
\hline $\mathrm{O} 6 W \quad \mathrm{H} 6 X \cdots \mathrm{O} 5 W$ & $0.94(1)$ & $1.73(2)$ & $2.645(5)$ & $164(3)$ \\
\hline $\mathrm{O} 6 W \quad \mathrm{H} 6 Y \cdots \mathrm{O} 2$ & $0.95(1)$ & $1.93(1)$ & $2.875(4)$ & $175(4)$ \\
\hline $\mathrm{O} 7 W \quad \mathrm{H} 7 X \cdots \mathrm{O} 2 W$ & $0.95(1)$ & $1.81(2)$ & $2.741(10)$ & $163(6)$ \\
\hline $\mathrm{O} 7 W \quad \mathrm{H} 7 Y \cdots \mathrm{O} 9^{\text {ix }}$ & $0.95(1)$ & $2.04(2)$ & $2.972(6)$ & $166(6)$ \\
\hline $\mathrm{O} 8 W W \quad \mathrm{H} 8 X \cdots \mathrm{O} 7 W$ & $0.95(1)$ & $1.99(3)$ & $2.927(8)$ & $167(9)$ \\
\hline $\mathrm{O} 8 W \quad \mathrm{H} 8 Y \cdots \mathrm{O} 3 W^{\mathrm{x}}$ & $0.96(1)$ & $2.07(5)$ & $2.901(8)$ & $145(7)$ \\
\hline
\end{tabular}

Symmetry codes: (ii) $\quad x, y, z+1 ; \quad$ (iii) $\quad x, y+1, \quad z+1 ; \quad$ (v) $x+1, \quad y+1, \quad z+1 ; \quad$ (vi) $\quad x+1, \quad y, \quad z+1 ; \quad$ (vii) $\quad x+1, \quad y, \quad z ; \quad$ (viii) $x \quad 1, y, z ;$ (ix) $x+1, y, z \quad 1 ;(\mathrm{x}) \quad x+1, \quad y+1, \quad z$.

$91.05(14)^{\circ}$, the trans octahedral angles are exactly $180^{\circ}$ due to the location of the metal centre at the inversion centre (see Table 4 for details). The centrosymmetric organic residue $\mathrm{H}_{2} \mathrm{pmd}^{2-}$ is coordinated to four metal centres with each $\mathrm{PO}_{3} \mathrm{H}$ group acting as a $\mu_{2}-\mathrm{O}, \mathrm{O}^{\prime}$ ligand between two such centres. Compound (II) does not show any porosity, and its supramolecular interactions are limited to the $\mathrm{O} 2 \mathrm{H} 2 \mathrm{Z} \cdots \mathrm{O} 4$ hydrogen bond and to $\mathrm{C} H \cdots \pi$ interactions (see Table 5 and Fig. 4 for details).

\subsection{Crystal structure of $\left[\left(\mathrm{UO}_{2}\right)_{3}\left(\mathrm{H}_{3} \mathrm{bmt}\right)_{2}\left(\mathrm{H}_{2} \mathrm{O}\right)_{2}\right] \cdot 14 \mathrm{H}_{2} \mathrm{O}$ (III)}

Compound (III) crystallizes in space group $P \overline{1}$, with the asymmetric unit being composed of a whole residue of (benzene-1,3,5-triyltris(methylene))triphosphonic acid $\left(\mathrm{H}_{3} \mathrm{bmt}^{3-}\right)$, one and a half crystallographically independent uranyl centres, a coordinated water molecule, and seven water molecules distributed over nine distinct crystallographic sites (Fig. 5a). Notably, even though the crystallization of (III) could only be achieved with the addition of HF to the reaction mixture [as for compound (I), see §2], fluoride anions do not seem to be included in the crystal structure. Elemental analysis on representative amounts of the isolated compound strongly point to the absence of fluoride anions (see \$2). In addition, no crystallographic evidence was found for the presence of fluoride anions.

The coordination environments around the two metal centres are different: while that of U1 resembles a squeezed centrosymmetric octahedron similar to that in compound (II) (Fig. $5 b$ ), the coordination environment of $\mathrm{U} 2$ bears strong similarities to the pentagonal bipyramid around $\mathrm{U} 1$ in compound (I) (Fig. 5c). The bond lengths around U2 are 1.765 (3) and 1.769 (3) $\AA$ for $\mathrm{U} 2=\mathrm{O}, 2.472(3) \AA$ for 


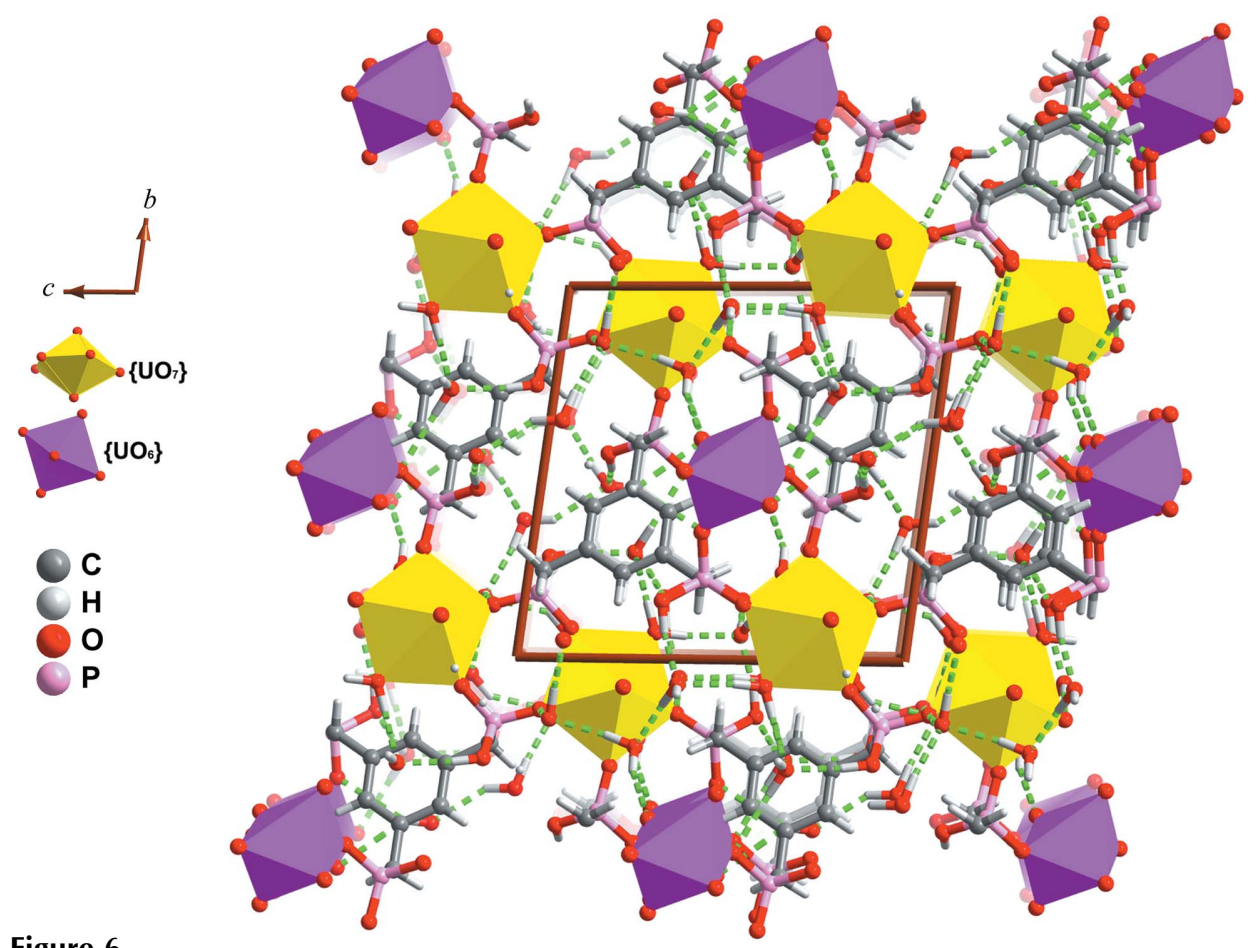

Figure 6

Crystal packing of (III) viewed along the [100] direction. Metal centres are represented as rose or yellow polyhedra, for octahedral or pentagonal bipyramidal geometries, respectively. $\mathrm{O} H \mathrm{H}$ interactions are depicted as dashed green lines. Crystallization water molecules with low site occupancy (O9W and $\mathrm{O} 10 \mathrm{~W}$ ) have been omitted for clarity.

nated to six metal centres, with all of the $\mathrm{PO}_{3} \mathrm{H}$ groups coordinating to the metal as $\mu_{2}-\mathrm{O}, \mathrm{O}^{\prime}$-ligands.

The water molecules occupy a continuous zigzag layer parallel to the (100) planes of the unit cell, occupying ca $26.9 \%$ of the total cell volume (ca $335 \AA$ ). The considerable number of donor and acceptor atoms contributes to the existence of a complex network of hydrogen bonds, showing rings with graph-set motifs $R_{4}^{4}(8)$ (two), $R_{4}^{4}(8), R_{5}^{3}(10)$, $R_{8}^{6}(16), R_{8}^{7}(17)$ and $R_{12}^{8}(23)$ (Grell et al., 1999; see Table 7 and Fig. 6 for additional details).

\subsection{FT-IR spectroscopy}

FT-IR spectroscopy on representative amounts of (I) (III) show the most important diagnostic bands attributed to the functional groups composing the organic ligands (Fig. 7). Due to the low wavenumbers in which the $U$ F vibrational modes appear (typically below $300 \mathrm{~cm}^{-1}$ ) these bands could not be used to establish unequivocally the absence of fluoride

U2 $\mathrm{O}_{\text {water }}$ and in the range 2.316 (3) 2.392 (3) $\AA$ for U2 $\mathrm{O}_{\text {phosphonate }}$ The mean plane formed by the equatorial atoms and the metal centre [largest deviation 0.205 (4) $\AA$ for O8] subtends angles with the axial $\mathrm{U}=\mathrm{O}$ bonds of 89.37 (15) and $89.80(15)^{\circ}$. The equatorial cis $\mathrm{O} \quad \mathrm{U} 2 \quad \mathrm{O}$ angles range from $66.10(10)$ to $77.17(10)^{\circ}$. For the U1 environment, the bond lengths are $1.774(3)$ for $\mathrm{U} 1=\mathrm{O}$, and 2.294 (4) and 2.307 (3) $\AA$ for U1 $\mathrm{O}_{\text {phosphonate. The equatorial cis octahedral }}$ O U1 O angles range from 88.08 (11) to $91.92(11)^{\circ}$ (see Table 6 for details). The organic residue $\mathrm{H}_{3} \mathrm{bmt}^{3-}$ is coordi-

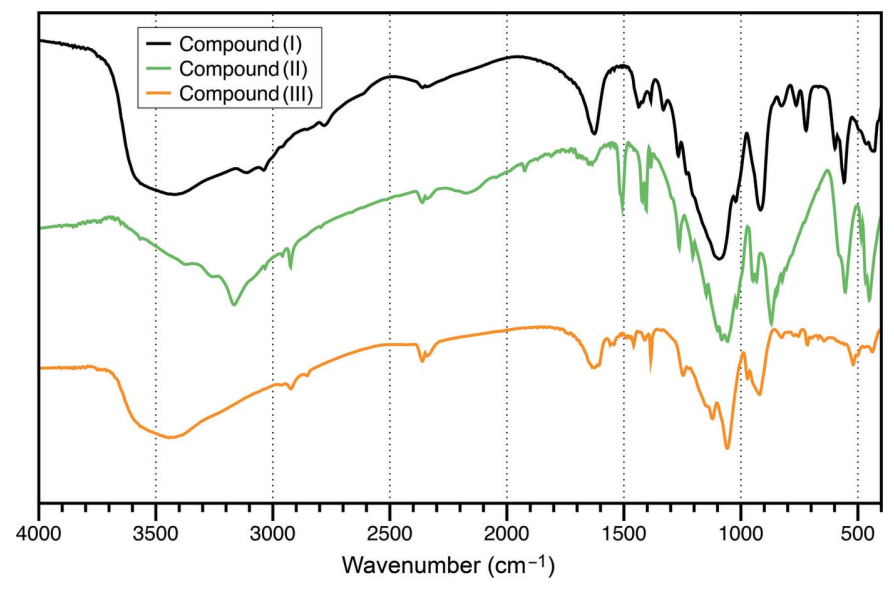

Figure 7

FT IR spectra of (I) (III) collected in the $4004000 \mathrm{~cm}^{1}$ range. anions in the structure of compound (III).

The FT-IR spectra of (I) and (III) show very broad bands in the range $36003200 \mathrm{~cm}^{-1}$ attributed to the $v(\mathrm{O} H)$ stretching modes of the coordinated water molecules. The inplane deformation $\delta\left(\mathrm{H}_{2} \mathrm{O}\right)$ bands of the water molecules are also clearly visible in the range $c a 16501600 \mathrm{~cm}^{-1}$. All of these bands are, as expected, absent from the spectrum of (II). The bands found between ca $32002800 \mathrm{~cm}^{-1}$ are attributed to the typical symmetric and asymmetric $v\left(\begin{array}{ll}\mathrm{C} & \mathrm{H}\end{array}\right)$ stretching vibrational modes, being much more visible for (II) due to the absence of the aforementioned broad band from the water molecules. The absence of water in (II) also permits observation in much more detail of the typical $v\left(\begin{array}{ll}\mathrm{PO} & \mathrm{H}\end{array}\right)$ stretching vibrational mode at $c a 3160 \mathrm{~cm}^{-1}$ (Fig. 7).

As we have reported previously for lanthanide-containing MOF structures with $\mathrm{H}_{4}$ pmd ligands (Vilela et al., 2014), the combination of $\delta\left(\mathrm{CH}_{2}\right)$ and $\nu(\mathrm{Ph})$ vibrational modes in the $c a$ $15201400 \mathrm{~cm}^{-1}$ spectral region is markedly visible in the spectrum of (II) due to the appearance of sharp strong bands which are typically absent from the remaining materials, particularly compound (I). The presence of this organic ligand is also notable as a strong broad band peaking at $c a 870 \mathrm{~cm}^{-1}$, attributed to a combination of the $\rho\left(\mathrm{CH}_{2}\right)$ and $\gamma(\mathrm{CH})$ modes (Vilela et al., 2014). Below ca $1100 \mathrm{~cm}^{-1}$, all spectra are strongly dominated by a multitude of bands arising from the phosphonate groups which overlap with the typical $v_{3}$ asymmetric stretching vibrational mode of the uranyl, $\mathrm{UO}_{2}^{2+}$, group. 
Particularly, between 1100 and $900 \mathrm{~cm}^{-1}$, various bands are attributed to the $v\left(\mathrm{PO}_{3}\right)$ modes of these groups, and at $c a 580$ and $554 \mathrm{~cm}^{-1}$, two markedly visible bands in the spectrum of (II) arise from the combination of the $\delta\left(\mathrm{PO}_{3}\right)$ and $\gamma(\mathrm{Ph})$ modes.

\section{Topological studies}

The frameworks (I) (III) can be conveniently described by employing a topological approach (Baburin et al., 2005; Blatov et al., 2004). This simplification approach, purely based on mathematical concepts, consists of reducing each network into objects that structurally could be envisaged as central nodes and connecting bridges (between two or more individual

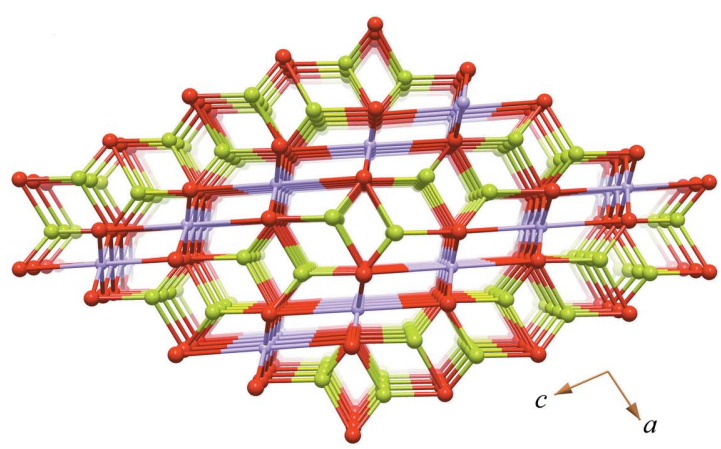

(I)

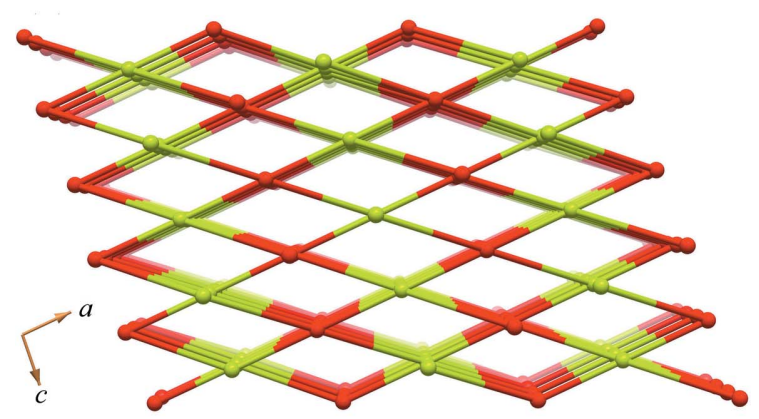

(II)

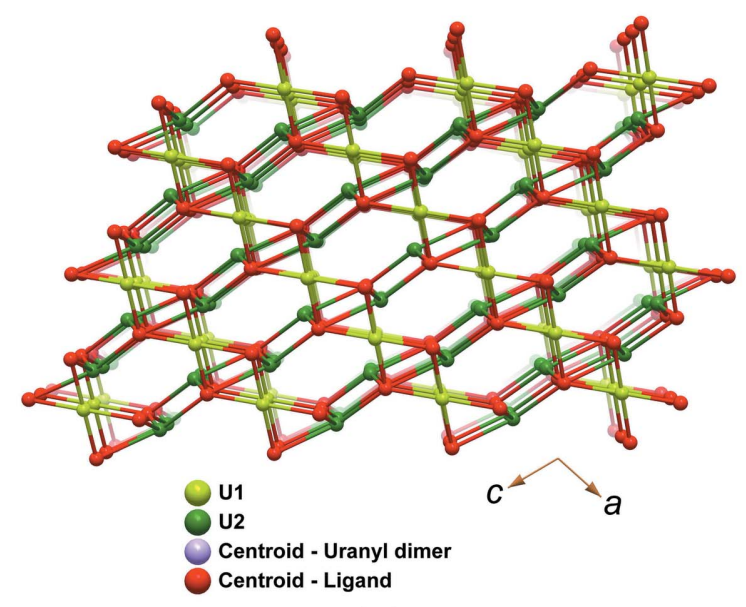

(III)

Figure 8

Topological representations of (I) (III). nodes). All topological studies have been performed using the software package TOPOS (Blatov, 2012). From the structures of (I) (III) a number of common structural features can be discerned among the frameworks: (i) they are assembled from one or two crystallographically independent uranyl-based metal centres; (ii) they contain a single organic residue [or a fragment in the case of (II)] in their asymmetric units; (iii) the organic ligands make physical connections between the uranyl-based metal centres.

Alexandrov et al. (2011) have considered that an organic ligand is of crucial structural importance in a framework when it establishes links between two or more metal centres $\left(\mu_{n}\right)$. This idea could be extended to other structurally important aggregates of atoms, such as the $\left\{\left(\mathrm{UO}_{2}\right) \mathrm{O}_{3}(\mu-\mathrm{F})\right\}_{2}$ dimer present in (II) and formed by the crystallographically independent $\mathrm{U} 2$ centres (see detailed structure description above). Therefore, for the performed topological studies, the centroids of each organic ligand and of the $\left\{\left(\mathrm{UO}_{2}\right) \mathrm{O}_{3}(\mu-\mathrm{F})\right\}_{2}$ dimer were taken as network nodes, along with the remaining uranyl metal centres. Two of the compounds are, in this way, trinodal: (I) is a 3,6,6-connected network with overall point symbol $\left\{4^{3}\right\}_{2}\left\{4^{7} \cdot 6^{7} \cdot 8\right\}_{2}\left\{4^{8} \cdot 6^{6} \cdot 8\right\}$, of which the $\left\{\left(\mathrm{UO}_{2}\right) \mathrm{O}_{3}(\mu-\mathrm{F})\right\}_{2}$ dimer and the organic ligands are both six-connected nodes (Fig. 8a); (III) is instead a 4,4,6-connected network (point symbol: $\left.\left\{4^{2} \cdot 8^{4}\right\}\left\{4^{4} \cdot 6^{2}\right\}_{2}\left\{4^{9} \cdot 6^{6}\right\}_{2}\right)$ having only the organic ligand as a sixconnected node (Fig. 8c). While (III) has a known topology deposited within the TOPOS database $(4,4,6 \mathrm{~T} 19)$, (I) corresponds to a new topological type. Searches in the Reticular Chemistry Structure Resource (RCSR; O'Keeffe et al., 2008) and in EPINET (Hyde et al., 2006) reveal that the nodal connectivity of compound (I) is, to the best of our knowledge, unprecedented among MOF structures.

Compound (II) is a much simpler network having only two nodes which are topologically identical: both the organic ligand and the uranyl group are 4-connected nodes with exactly identical coordination shells up to $N_{10}(=1489)$ (Fig. $8 b$ ). In this way, this network is 4-connected uninodal with point symbol $\left\{4^{5} \cdot 8\right\}$ and topology identical to that of the $\mathrm{CdSO}_{4}$ compound (type cds).

\section{Conclusions}

Three new MOF compounds based on uranyl groups coordinated to polyphosphonate-bearing ligands were isolated from hydrothermal synthesis and structurally characterized in the solid state. Compound (I) shows two different uranyl environments with pentagonal bipyramidal geometries, from which one comprises a centrosymmetric bimetallic cluster formed by two $\mathrm{F}^{-}$bridges. In contrast to the previously prepared materials with lanthanides and the ligand $\mathrm{H}_{6} \mathrm{nmp}$, which comprised two-dimensional coordination polymers (Silva et al., 2011; Cunha-Silva et al., 2007), compound (I) comprises a highly porous three-dimensional network.

The coordination geometry around the uranyl group in (II) resembles a squeezed octahedron. The structure comprises layers of inorganic uranyl phosphonates alternating with organic layers composed by the hydrocarbon part of the 
ligand. This resembles the packing observed in the previously prepared lanthanide materials with the same ligand (Vilela, Mendes et al., 2013; Shi et al., 2008). In contrast to these compounds (II) is fully dehydrated.

Compound (III) is based on two uranyl environments with different coordination geometries, one being a pentagonal bipyramid and the other a squeezed octahedron. In relation to the previously prepared compounds with $\mathrm{H}_{6}$ bmt and lanthanides (Vilela, Firmino et al., 2013; Vilela et al., 2012), compound (III) exhibits a considerably larger cavity occupied by a larger number of water molecules. While compounds (II) and (III) have known topological types, compound (I) corresponds to an unprecedented topological type among MOF structures.

We thank Fundação para a Ciência e a Tecnologia (FCT, Portugal), the European Union, QREN, FEDER, COMPETE and Laboratório Associado Centro de Investigação em Materiais Cerâmicos e Compósitos, CICECO (Pest C-CTM/ LA0011/2013), the research unit QOPNA (PEst-C/QUI/ UI0062/2013) for their general funding scheme. We further thank FCT for the R\&D project PTDC/QUI-QUI/098098/ 2008 (FCOMP-01-0124-FEDER-010785), and for specific funding towards the purchase of a single-crystal diffractometer. We are also grateful to FCT for the $\mathrm{PhD}$ grant No. SFRH/BD/66371/2009 (to SMFV) and the post-doctoral grants SFRH/BPD/47087/2008 (to BM) and SFRH/BPD/ $63736 / 2009$ (to JAF).

\section{References}

Adelani, P. O., Oliver, A. G. \& Albrecht Schmitt, T. E. (2011). Cryst. Growth Des. 11, 30723080.

Alexandrov, E. V., Blatov, V. A., Kochetkov, A. V. \& Proserpio, D. M. (2011). CrystEngComm, 13, 39473958.

Almeida Paz, F. A., Shi, F. N., Klinowski, J., Rocha, J. \& Trindade, T. (2004). Eur. J. Inorg. Chem. pp. 27592768.

Almeida Paz, F. A., Rocha, J., Klinowski, J., Trindade, T., Shi, F. N. \& Mafra, L. (2005). Prog. Solid State Chem. 33, 113125.

Alsobrook, A. N., Alekseev, E. V., Depmeier, W. \& Albrecht Schmitt, T. E. (2011). Cryst. Growth Des. 11, 23582367.

Andrews, M. B. \& Cahill, C. L. (2013). Chem. Rev. 113, 11211136.

Baburin, I. A., Blatov, V. A., Carlucci, L., Ciani, G. \& Proserpio, D. M. (2005). J. Solid State Chem. 178, 24522474.

Blatov, V. A. (2012). Struct. Chem. 23, 955963.

Blatov, V. A., Carlucci, L., Ciani, G. \& Proserpio, D. M. (2004). CrystEngComm, 6, 377395.

Brandenburg, K. (2009). DIAMOND. Crystal Impact GbR, Bonn, Germany.
Bruker (2008). APEX2, SADABS, SAINT Plus and SHELXTL. Bruker AXS, Madison, Wisconsin, USA.

Cunha Silva, L., Ananias, D., Carlos, L. D., Almeida Paz, F. A. \& Rocha, J. (2009). Z. Kristallogr. 224, 261272.

Cunha Silva, L., Lima, S., Ananias, D., Silva, P., Mafra, L., Carlos, L. D., Pillinger, M., Valente, A. A., Paz, F. A. A. \& Rocha, J. (2009). J. Mater. Chem. 19, 26182632.

Cunha Silva, L., Mafra, L., Ananias, D., Carlos, L. D., Rocha, J. \& Almeida Paz, F. A. (2007). Chem. Mater. 19, 35273538.

Grell, J., Bernstein, J. \& Tinhofer, G. (1999). Acta Cryst. B55, 1030 1043.

Hyde, S. T., Delgado Friedrichs, O., Ramsden, S. J. \& Robins, V. (2006). Solid State Sci. 8, 740752.

Kottke, T. \& Stalke, D. (1993). J. Appl. Cryst. 26, 615619.

O'Keeffe, M., Peskov, M. A., Ramsden, S. J. \& Yaghi, O. M. (2008). Acc. Chem. Res. 41, 17821789.

Oxford Cryosystems (2006). Cryopad. Oxford Cryosystems Ltd, Oxford, England.

Rocha, J., Paz, F. A. A., Shi, F. N., Ferreira, R. A. S., Trindade, T. \& Carlos, L. D. (2009). Eur. J. Inorg. Chem. pp. 4931 4945.

Sheldrick, G. M. (2008). Acta Cryst. A64, 112122.

Shi, F. N., Paz, F. A. A., Girginova, P. I., Amaral, V. S., Rocha, J., Klinowski, J. \& Trindade, T. (2006). Inorg. Chim. Acta, 359, 1147 1158.

Shi, F. N., Paz, F. A. A., Girginova, P. I., Rocha, J., Amaral, V. S., Klinowski, J. \& Trindade, T. (2006). J. Mol. Struct. 789, 200 208.

Shi, F. N., Trindade, T., Rocha, J. \& Paz, F. A. A. (2008). Cryst. Growth Des. 8, 39173920.

Silva, P., Fernandes, J. A. \& Almeida Paz, F. A. (2012). Acta Cryst. E68, m294 m295.

Silva, P., Vieira, F., Gomes, A. C., Ananias, D., Fernandes, J. A., Bruno, S. M., Soares, R., Valente, A. A., Rocha, J. \& Paz, F. A. (2011). J. Am. Chem. Soc. 133, 1512015138.

Soares Santos, P. C., Cunha Silva, L., Paz, F. A., Ferreira, R. A., Rocha, J., Carlos, L. D. \& Nogueira, H. I. (2010). Inorg. Chem. 49, 34283440.

Thuéry, P. (2013). Cryst. Growth Des. 52, 435447.

Thuéry, P., Masci, B. \& Harrowfield, J. (2013). Cryst. Growth Des. 13, 32163224.

Vilela, S. M. F., Ananias, D., Fernandes, J. A., Silva, P., Gomes, A. C., Silva, N. J. O., Rodrigues, M. O., Tomé, J. P. C., Valente, A. A., Ribeiro Claro, P., Carlos, L. D., Rocha, J. \& Almeida Paz, F. A. (2014). J. Mater. Chem. C, doi: 10.1039/c3tc32114b.

Vilela, S. M. F., Ananias, D., Gomes, A. C., Valente, A. A., Carlos, L. D., Cavaleiro, J. A. S., Rocha, J., Tomé, J. P. C. \& Almeida Paz, F. A. (2012). J. Mater. Chem. 22, 1835418371.

Vilela, S. M. F., Firmino, A. D. G., Mendes, R. F., Fernandes, J. A., Ananias, D., Valente, A. A., Ott, H., Carlos, L. D., Rocha, J., Tomé, J. P. C. \& Almeida Paz, F. A. (2013). Chem. Commun. 49, 6400 6402.

Vilela, S. M. F., Mendes, R. F., Silva, P., Fernandes, J. A., Tomé, J. P. C. \& Paz, F. A. A. (2013). Cryst. Growth Des. 13, 543560. 